\title{
Pengaruh konsentrasi IAA (Indole Acetic Acid) dan BAP (Benzyl Amino Purine) terhadap pertumbuhan awal sambung samping jambu biji (Psidium guajava l.) Var. Kristal
}

\author{
(The effect of IAA (Indole Acetic Acid) and BAP (Benzyl Amino Purine) concentration on \\ early growth budding of guava (Psidium guajava l.) Var. Kristal in side grafting propagation \\ method)
}

\author{
H. Pratomo, Karno, B. A. Kristanto \\ Agroecotechnology, Faculty of Animal and Agricultural Sciences, Diponegoro University \\ Tembalang Campus, Semarang 50275 - Indonesia \\ Corresponding E-mail: hendrapratommo@gmail.com
}

\begin{abstract}
The purpose of this research was to study the influence of various concentrations of IAA and BAP on early growth budding of guava (Psidium guajava L.) Var. Kristal in side grafting propagation method. The experiment used completely randomized factorial design. The first factor was various concentrations of IAA $(0,100$, and $200 \mathrm{ppm})$ and the second factor was various concentrations of BAP $(0,100$, and 200 ppm). Each treatment was repeated three times. Parameters observed were the time of bud break, time of shoot emergence, and shoot length. The data were analyzed by variance and continued analyzed by Duncan Multiple Range Test. The results showed that the level of IAA concentration gave effect $(\mathrm{P}<0,05)$ to time of shoot emergence and shoot length. Level of BAP concentrations gave significant effect $(\mathrm{P}<0,05)$ to the time of bud break, time of shoot emergence, and shoot length. The interaction between the concentration level of IAA and BAP had significant effect $(\mathrm{P}<0,05)$ on the time of bud break, time of shoot emergence and shoot length.
\end{abstract}

Keywords : Guava, Psidium guajava, Side Grafting, IAA, BAP.

\begin{abstract}
ABSTRAK
Penelitian ini bertujuan untuk mengkaji pengaruh pemberian berbagai konsentrasi IAA dan BAP terhadap pertumbuhan awal sambung samping jambu biji (Psidium guajava L.) Var. Kristal. Penelitian disusun dengan rancangan acak lengkap faktorial dengan faktor pertama adalah konsentrasi IAA $(0,100$, dan $200 \mathrm{ppm})$ dan faktor kedua adalah konsentrasi BAP (0, 100, dan $200 \mathrm{ppm})$. Masing-masing perlakuan diulang 3 kali. Parameter yang diamati yaitu umur keberhasilan, waktu pecah tunas dan panjang tunas. Data dianalisis ragam dan dilanjutkan uji DMRT (Duncan Multiple Range Test). Hasil penelitian menunjukkan bahwa taraf konsentrasi IAA memberikan pengaruh nyata $(\mathrm{P}<0,05)$ terhadap waktu pecah tunas dan panjang tunas. Taraf konsentrasi BAP memberikan pengaruh nyata $(\mathrm{P}<0,05)$ terhadap umur keberhasilan, waktu pecah tunas dan panjang tunas. Interaksi antara taraf konsentrasi IAA dan BAP berpengaruh nyata $(\mathrm{P}<0,05)$ terhadap umur keberhasilan, waktu pecah tunas dan panjang tunas. Kata kunci: Jambu biji, Psidium guajava, Sambung samping, IAA, BAP.
\end{abstract}

\section{PENDAHULUAN}

Indonesia termasuk negara dengan tingkat konsumsi buah-buahan yang rendah dengan ratarata konsumsi sebesar $40 \mathrm{~kg} / \mathrm{kapita} / \mathrm{tahun}$. Nilai tersebut masih dibawah standar minimal FAO yaitu sebesar 65,75 kg/kapita/tahun (Badan Pusat Statistik, 2011). Proyeksi tersebut menunjukkan adanya peluang untuk mengembangkan komoditas buah-buahan. Komoditas buah yang berpeluang untuk dikembangkan adalah jambu kristal (Psidium guajava L). Usaha pengadaan bibit 
tanaman jambu kristal dapat diperoleh dari perbanyakan generatif maupun vegetatif. Sambung samping adalah teknik menggabungkan dua batang tanaman yang berbeda jenis atau varietas, dengan cara menempelkan kedua batang sehingga penggabungan dua batang ini menjadi satu tanaman (Qing Xu, 2016).

Pertumbuhan awal sambung samping sangat dipengaruhi oleh kompatibilitas sambungan antara entres dan batang bawah. Sambungan yang gagal disebabkan adanya inkompabilitas antara entres dan batang bawah. Inkompabilitas sambungan disebabkan oleh keadaan fisiologis tanaman. Usaha yang dapat dilakukan untuk mencegah terjadinya inkompabilitas adalah dengan pemberian zat pengatur tumbuh (ZPT). ZPT adalah senyawa organik yang dapat merangsang, menghambat, serta merubah proses fisiologi tumbuhan (Eleos, 2013). Auksin dan sitokinin adalah ZPT yang memiliki peran pada pertumbuhan dan perkembangan tanaman. Auksin dan sitokinin merangsang aktivitas kambium dan pembentukan floem pada batang (Reinhardt et al., 2000). Auksin dan sitokinin umunya dapat meningkatkan laju pertumbuhan tunas (Adeyemi et al., 2016).

Auksin umunya berperan dalam menginduksi pembentukan kalus, memacu pemanjangan dan pembelahan sel didalam jaringan kambium (Lestari, 2010). Diferensiasi floem diinduksi oleh IAA dengan kadar yang rendah, sedangkan pada diferensiasi xilem membutuhkan konsentrasi IAA dengan kadar yang lebih tinggi, pada jaringan pembuluh yang terluka, jalur IAA yang terputus dapat membentuk jalur baru melalui sel parenkim, sehingga akan terjadi regenerasi jaringan disekitar luka (Aloni, 2003).

Sitokinin dibutuhkan oleh jaringan tanaman untuk pengembangan siklus sel, pembelahan sel, dan pemeliharaan meristem (Hirose et al., 2008). BAP adalah salah satu sitokinin yang berfungsi sebagai perangsang pertumbuhan tunas, metabolisme sel, pembelahan sel, dan mengurangi dominansi apikal (Eleos, 2013). Berdasarkan hasil penelitian sebelumnya dapat diketahui bahwa pemberian IBA 100 ppm pada sambung samping tanaman srikaya menghasilkan persentase bibit jadi tertinggi, waktu muncul tunas tercepat, serta rata-rata panjang tunas tertinggi (Yulianto et al., 2015). Percobaan pengaruh konsentrasi BAP terhadap pertumbuhan awal entres pada okulasi durian menunjukkan bahwa BAP mampu mengoptimalkan pertumbuhan awal entres tiga varietas durian (Setyaningrum, 2012).

Penelitian ini bertujuan untuk mengkaji pertumbuhan awal sambung samping tanaman jambu kristal pada berbagai taraf konsentrasi IAA dan BAP yang berbeda, serta untuk mengetahui interaksi antara taraf konsentrasi IAA dan BAP terhadap pertumbuhan awal sambung samping tanaman jambu kristal.

\section{MATERI DAN METODE}

Penelitian dilaksanakan pada tanggal 15 Februari - 17 Mei 2017 di Kebun Cepoko, UPTD Balai Benih Pertanian, Kecamatan Gunung Pati, Kota Semarang.

\section{Materi}

Bahan yang digunakan dalam penelitian ini adalah batang bawah jambu biji varietas lokal dengan umur tanaman kurang lebih 8 bulan, entres jambu kristal, bubuk IAA dan BAP, aquades, alkohol $70 \%, \mathrm{NaOH} 1 \mathrm{~N}$, media tanam: tanah, sekam dan pupuk kandang kambing dengan perbandingan 1:1:1, dan pupuk organik granul. Alat yang digunakan dalam penelitian ini antara lain erlenmeyer, gelas ukur, timbangan analitik, spatula, corong, gunting pangkas, pisau okulasi, plastik okulasi, cangkul, polibag ukuran $35 \times 35$ $\mathrm{cm}$, ember, dan gembor.

\section{Metode Penelitian}

Rancangan percobaan yang digunakan adalah rancangan acak lengkap (RAL) faktorial $3 \times 3$ dengan 3 Ulangan. Faktor pertama adalah konsentrasi IAA (Indole Acetic Acid) dengan 3 taraf perlakuan yaitu A0: $0 \mathrm{ppm}, \mathrm{A1}: 100 \mathrm{ppm}$, dan A2: 200 ppm. Faktor kedua adalah konsentrasi BAP (Benzil Amino Purin) dengan 3 taraf perlakuan yaitu B0: 0 ppm, B1: 100 ppm, dan B2: 200 ppm. Kombinasi antara dua faktor perlakuan menghasilkan 9 kombinasi perlakuan. Setiap kombinasi perlakuan dilakukan 3 kali ulangan sehingga diperoleh 27 unit percobaan. Data yang diperoleh dianalisis dengan menggunakan prosedur analisis ragam (analysis of 
variance / anova) pada taraf 5\%. Jika terdapat pengaruh perlakuan maka dilanjutkan uji wilayah ganda duncan untuk mengetahui perbedaan.

\section{Pelaksanaan}

Penelitian ini diawali penyiapan larutan IAA dan BAP. Pembuatan larutan IAA $100 \mathrm{ppm}$ dan 200 ppm membutuhkan $0,1 \mathrm{mg}$ dan $0,2 \mathrm{mg}$ bubuk IAA. Bubuk IAA ditimbang dan dimasukkan kedalam erlenmeyer $50 \mathrm{ml}$. Bubuk IAA ditetesi dengan $10 \mathrm{ml}$ alkohol $70 \%$ dan digojog hingga larut. Aquades ditambahkan hingga volume mencapai $1000 \mathrm{ml}$. Pembuatan larutan BAP 100 ppm dan 200 ppm membutuhkan 0,1 mg dan 0,2 mg bubuk BAP. Bubuk BAP ditimbang dan dimasukkan kedalam erlenmeyer $50 \mathrm{ml}$. Bubuk BAP ditetesi dengan $10 \mathrm{ml} \mathrm{NaOH} 1 \mathrm{~N}$ dan digojog hingga larut. Aquades ditambahkan hingga volume mencapai $1000 \mathrm{ml}$. Pelaksanaan penyambungan diawali dengan menyiapkan entres dari tanaman jambu kristal. Selanjutnya, pembuatan jendela okulasi batang bawah. Perlakuan dilakukan dengan cara mengoleskan larutan IAA dan BAP pada jendela okulasi sesuai dengan perlakuan taraf konsentrasinya. Penyambungan dilakukan dengan menyisipkan batang entres pada jendela okulasi batang bawah. Sambungan diikat dengan tali plastik hingga rapat. Pemeliharaan tanaman meliputi penyiraman, pemupukan, penyiangan gulma dan pengendalian hama penyakit.

\section{Parameter Pengamatan}

(1) Umur keberhasilan sambung, pengamatan dengan cara melihat mata tunas yang tumbuh (2) Waktu pecah tunas, pecah tunas yang dimaksud adalah saat bakal daun pada tunas entres pertama kali muncul. (3) Panjang tunas, diukur dari pangkal tunas hingga titik tumbuh. (4) Diameter tunas, diameter tunas diukur pada pangkal tunas yang tumbuh. (5) Jumlah daun terbuka, dihitung berdasarkan jumlah daun yang terbentuk dan membuka sempurna pada tunas-tunas yang tumbuh. (7) Lebar tajuk, diukur dari ujung daun yang satu ke ujung lainnya.

\section{HASIL DAN PEMBAHASAN}

\section{Umur Keberhasilan}

Hasil penelitian mengenai pengaruh taraf konsentrasi IAA dan BAP terhadap umur keberhasilan disajikan pada Tabel 1.

Hasil analisis (Tabel 1) menunjukkan bahwa taraf konsentrasi IAA tidak memberikan pengaruh nyata $(\mathrm{P}<0,05)$ terhadap umur keberhasilan, sedangkan taraf konsentrasi BAP memberikan pengaruh nyata $(\mathrm{P}<0,05)$ terhadap umur keberhasilan. Auksin berperan dalam memacu pembentukan kalus pada batang yang terluka. Menurut Aloni (2003) bahwa ketika jaringan pembuluh terluka, jalur IAA yang terputus dapat membentuk jalur baru melalui sel parenkim, sehingga akan terjadi regenerasi jaringan disekitar

Tabel 1. Umur keberhasilan

\begin{tabular}{|c|c|c|c|c|}
\hline \multirow{2}{*}{$\begin{array}{l}\text { Konsentrasi } \\
\text { BAP (ppm) }\end{array}$} & \multicolumn{3}{|c|}{ Konsentrasi IAA (ppm) } & \multirow{2}{*}{ Rata-rata } \\
\hline & 0 & 100 & 200 & \\
\hline & \multicolumn{4}{|c|}{ 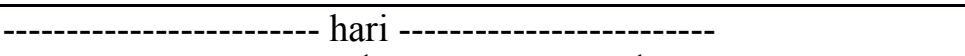 } \\
\hline 0 & $46,67^{\mathrm{a}}$ & $36,33^{\mathrm{bc}}$ & $36,00^{\mathrm{bc}}$ & $39,66^{\mathrm{a}}$ \\
\hline 100 & $35,33^{\mathrm{bc}}$ & $40,67^{\mathrm{ab}}$ & $35,33^{\text {bc }}$ & $37,11^{\mathrm{ab}}$ \\
\hline 200 & $31,00^{\mathrm{c}}$ & $32,00^{\mathrm{c}}$ & $38,50^{\mathrm{bc}}$ & $33,83^{\mathrm{b}}$ \\
\hline Rata-rata & 37,66 & 36,33 & 36,61 & \\
\hline
\end{tabular}

Superskrip yang berbeda pada kolom dan baris rata-rata yang sama menunjukkan perbedaan nyata $(\mathrm{P}<0,05)$.

Superskrip yang berbeda pada matrik interaksi menunjukkan perbedaan nyata $(\mathrm{P}<0,05)$. 
luka. Sitokinin berperan dalam memelihara jaringan yang terluka akibat sayatan. Menurut Hirose dkk. (2008) bahwa sitokinin dibutuhkan oleh jaringan tanaman untuk pengembangan siklus sel, pembelahan sel, dan pemeliharaan meristem.

Interaksi antara taraf konsentrasi IAA dan BAP (Tabel 1) berpengaruh nyata $(\mathrm{P}<0,05)$ terhadap umur keberhasilan. Umur keberhasilan pada perlakuan konsentrasi IAA 0 ppm dengan pemberian BAP 0 ppm, 100 ppm dan 200 ppm semakin menurun. Umur keberhasilan pada perlakuan konsentrasi IAA $100 \mathrm{ppm}$ dengan pemberian BAP 100 ppm meningkat, namun pada BAP 200 ppm menurun. Sedangkan pada konsentrasi IAA $200 \mathrm{ppm}$ dengan pemberian BAP 100 ppm menurun, namun pada BAP 200 ppm meningkat.

Umur keberhasilan pada perlakuan konsentrasi BAP $0 \mathrm{ppm}$ dengan pemberian IAA 0 ppm, 100 ppm dan 200 ppm semakin menurun. Umur keberhasilan pada perlakuan konsentrasi BAP $100 \mathrm{ppm}$ dengan pemberian IAA $100 \mathrm{ppm}$ meningkat, namun pada IAA 200 ppm menurun. Sedangkan pada konsentrasi BAP 200 ppm dengan pemberian IAA $0 \mathrm{ppm}, 100 \mathrm{ppm}$ dan 200 ppm semakin meningkat (Tabel 1). Hal ini menunjukkan bahwa hanya pada pemberian IAA $100 \mathrm{ppm}$ saja atau BAP $100 \mathrm{ppm}$ saja sudah dapat menurunkan nilai rata-rata umur keberhasilan. Pemberian auksin dan sitokinin berperan dalam mempercepat pertautan batang bawah dan batang atas. Menurut Eleos (2013) bahwa zat pengatur tumbuh mempengaruhi proses fisiologi tumbuhan. Lestari (2010) menyatakan bahwa auksin pada umumnya digunakan untuk menginduksi pembentukan kalus. Ditambahkan oleh Febriani
(2012) bahwa sitokinin efektif untuk menginduksi pertumbuhan tunas.

\section{Waktu Pecah Tunas}

Hasil penelitian mengenai pengaruh taraf konsentrasi IAA dan BAP terhadap waktu pecah tunas disajikan pada Tabel 2. Hasil analisis (Tabel 2) menunjukkan bahwa taraf konsentrasi IAA memberikan pengaruh nyata $(\mathrm{P}<0,05)$ terhadap waktu pecah tunas, begitu pula taraf konsentrasi BAP memberikan pengaruh nyata $(\mathrm{P}<0,05)$ terhadap waktu pecah tunas. Auksin berperan dalam memacu perkembangan sel pada tunas yang sedang berkembang. Menurut Campbell (2003) bahwa auksin merupakan hormon yang berperan terhadap pemanjangan sel, pada tunas muda yang sedang berkembang akan terus memanjang hingga tunas tumbuh tinggi. Sitokinin berperan dalam menginduksi pertumbuhan tunas, sehingga pemberian BAP dapat mempercepat waktu pecah tunas. Menurut Febriani (2012) bahwa BAP efektif menginduksi pembentukan tunas. Ditambahkan oleh Eleos (2013) bahwa benzil amino purin adalah salah satu sitokinin yang berfungsi sebagai perangsang pertumbuhan tunas, mengurangi dominansi apikal, serta mendorong inisiasi tunas lateral.

Interaksi antara taraf konsentrasi IAA dan BAP (Tabel 2) berpengaruh nyata $(\mathrm{P}<0,05)$ terhadap waktu pecah tunas. Berdasarkan Ilustrasi 2 menunjukkan bahwa waktu pecah tunas pada perlakuan konsentrasi IAA 0 ppm dengan pemberian BAP 0 ppm, 100 ppm dan 200 ppm semakin menurun. Waktu pecah tunas pada konsentrasi IAA 100 ppm dengan pemberian BAP

Tabel 2. Waktu pecah tunas

\begin{tabular}{|c|c|c|c|c|}
\hline \multirow{2}{*}{$\begin{array}{l}\text { Konsentrasi } \\
\text { BAP (ppm) }\end{array}$} & \multicolumn{3}{|c|}{ Konsentrasi IAA (ppm) } & \multirow{2}{*}{ Rata-rata } \\
\hline & 0 & 100 & 200 & \\
\hline & \multicolumn{4}{|c|}{------------------------- hari ------------------------ } \\
\hline 0 & $66,33^{\mathrm{a}}$ & $44,67^{\mathrm{b}}$ & $42,33^{b}$ & $51,11^{\mathrm{a}}$ \\
\hline 100 & $46,33^{b}$ & $43,67^{\mathrm{b}}$ & $43,33^{b}$ & $44,44^{b}$ \\
\hline 200 & $43,67^{b}$ & $38,33^{\mathrm{b}}$ & $45,83^{\mathrm{b}}$ & $42,61^{\mathrm{b}}$ \\
\hline Rata-rata & $52,11^{\mathrm{a}}$ & $42,22^{\mathrm{b}}$ & $43,83^{b}$ & \\
\hline
\end{tabular}

Superskrip yang berbeda pada kolom dan baris rata-rata yang sama menunjukkan perbedaan nyata $(\mathrm{P}<0,05)$.

Superskrip yang berbeda pada matrik interaksi menunjukkan perbedaan nyata $(\mathrm{P}<0,05)$. 
0 ppm, 100 ppm dan 200 ppm juga semakin menurun. Sedangkan pada konsentrasi IAA 200 ppm dengan pemberian BAP 0 ppm, 100 ppm dan 200 ppm semakin meningkat.

Waktu pecah tunas pada perlakuan konsentrasi BAP 0 ppm dengan pemberian IAA 0 ppm, 100 ppm dan 200 ppm semakin menurun. Waktu pecah tunas pada konsentrasi BAP 100 ppm dengan pemberian IAA 0 ppm, $100 \mathrm{ppm}$ dan 200 ppm juga semakin menurun. Sedangkan pada konsentrasi BAP 200 ppm dengan pemberian BAP 100 ppm menurun, namun pada BAP 200 ppm meningkat. Hal ini menunjukkan bahwa hanya pada pemberian IAA 100 ppm saja atau BAP 100 ppm saja sudah dapat menurunkan nilai rata-rata waktu pecah tunas (Tabel 2). Auksin dan sitokinin dapat memacu aktivitas kambium pada batang, sehingga dapat dimungkinkan waktu pecah tunas lebih cepat. Hal ini sesuai dengan pendapat Reinhardt dkk. (2000) bahwa auksin dan sitokinin merangsang aktivitas kambium dan pembentukkan floem. Menurut Adeyemi dkk. (2016) bahwa laju pertumbuhan tunas umumnya lebih tinggi dengan kombinasi auksin dan sitokinin dibandingkan hanya menggunakan auksin atau sitokinin saja.

\section{Panjang Tunas}

Hasil penelitian mengenai pengaruh taraf konsentrasi IAA dan BAP terhadap panjang tunas disajikan pada Tabel 3. Hasil analisis (Tabel 3) menunjukkan bahwa taraf konsentrasi IAA memberikan pengaruh nyata $(\mathrm{P}<0,05)$ terhadap panjang tunas, begitu juga taraf konsentrasi BAP memberikan pengaruh nyata $(\mathrm{P}<0,05)$ terhadap panjang tunas. Menurut Widyawati (2010) bahwa auksin mempunyai peranan dalam kenaikan sintesis protein, sehingga dapat digunakan sebagai sumber tenaga untuk pertumbuhan. Menurut Azizi dkk. (2015) bahwa sitokinin berperan positif terhadap pertumbuhan tunas, mendukung pembelahan sel dan meningkatkan ukuran meristem.

Interaksi antara taraf konsentrasi IAA dan BAP (Tabel 3) berpengaruh nyata $(\mathrm{P}<0,05)$ terhadap panjang tunas. Panjang tunas pada konsentrasi IAA $0 \mathrm{ppm}$ dengan pemberian BAP 100 ppm meningkat, namun pada BAP 200 ppm menurun. Panjang tunas pada konsentrasi IAA 100 ppm dengan pemberian BAP 100 ppm menurun, namun pada BAP 200 ppm meningkat. Sedangkan pada konsentrasi IAA 200 ppm dengan pemberian BAP 100 ppm menurun, namun pada BAP 200 ppm meningkat (Tabel3).

Panjang tunas pada perlakuan konsentrasi BAP 0 ppm dengan pemberian IAA $100 \mathrm{ppm}$ meningkat, namun pada IAA 200 ppm menurun. Panjang tunas pada konsentrasi BAP 100 ppm semakin menurun dengan pemberian IAA $0 \mathrm{ppm}$, $100 \mathrm{ppm}$ dan $200 \mathrm{ppm}$. Sedangkan pada konsentrasi BAP $200 \mathrm{ppm}$ dengan pemberian IAA $100 \mathrm{ppm}$ meningkat, namun pada IAA $200 \mathrm{ppm}$ menurun (Tabel3). Hal ini menunjukkan bahwa hanya pada pemberian IAA $100 \mathrm{ppm}$ saja atau BAP 100 ppm saja sudah dapat meningkatkan nilai rata-rata panjang tunas. Auksin dan sitokinin merupakan hormon yang berperan dalam perkembangan sel, sehingga dapat memengaruhi pertambahan panjang batang. Menurut Widyastuti dan Tjokrokusumo (2007) bahwa auksin memengaruhi diferensiasi sel yang berdampak pada pertambahan panjang batang. Lakitan (2001)

Tabel 3. Panjang tunas pada minggu ke-10

\begin{tabular}{|c|c|c|c|c|}
\hline \multirow{2}{*}{$\begin{array}{l}\text { Konsentrasi } \\
\text { BAP (ppm) }\end{array}$} & \multicolumn{3}{|c|}{ Konsentrasi IAA (ppm) } & \multirow{2}{*}{ Rata-rata } \\
\hline & 0 & 100 & 200 & \\
\hline 0 & $2,37^{\mathrm{d}}$ & $12,00^{\mathrm{a}}$ & $3,67^{\mathrm{d}}$ & $6,01^{\mathrm{ab}}$ \\
\hline 100 & $9,70^{\mathrm{b}}$ & $3,87^{\mathrm{d}}$ & $3,63^{\mathrm{d}}$ & $5,73^{\mathrm{b}}$ \\
\hline 200 & $6,30^{\mathrm{c}}$ & $8,60^{\mathrm{b}}$ & $5,65^{\mathrm{c}}$ & $6,85^{\mathrm{a}}$ \\
\hline Rata-rata & $6,12^{\mathrm{b}}$ & $8,15^{\mathrm{a}}$ & $4,32^{\mathrm{c}}$ & \\
\hline
\end{tabular}

Superskrip yang berbeda pada kolom dan baris rata-rata yang sama menunjukkan perbedaan nyata $(\mathrm{P}<0,05)$.

Superskrip yang berbeda pada matrik interaksi menunjukkan perbedaan nyata $(\mathrm{P}<0,05)$. 
menyatakan bahwa auksin akan memacu pemanjangan sel-sel yang menyebabkan pemanjangan batang. Menurut Campbell dkk. (2003) bahwa auksin dan sitokinin merupakan fitohormon yang berperan terhadap proses pemanjangan sel, pada tunas muda yang sedang berkembang akan terus memanjang hingga tunas tumbuh tinggi.

\section{KESIMPULAN}

Kesimpulan dari hasil penelitian adalah pemberian konsentrasi IAA 100 ppm sudah dapat mempercepat waktu pecah tunas dan meningkatkan panjang tunas. Perlakuan konsentrasi BAP 100 ppm sudah dapat mempercepat umur keberhasilan, waktu pecah tunas dan meningkatkan panjang tunas.

\section{DAFTAR PUSTAKA}

Adeyemi, O.A., P. Lenka, P. Ales, N. Ondrej, D. Karel, and V. S. Johan. 2016. Auxincytokinin interaction and variations in their metabolic products in the regulation of organogenesis in two Eucomis Spesies. J. New Biotech. 33. 883-890.

Aloni, R. 2003. The Induction of Vascular Tissues by Auxin. Department of Plant Sciences. Tel Aviv University, Israel.

Aloni, R., L. Karni, G. Deveturero, Z. Levin, R. Cohen, N. Kazir, M. L. Pompan, M. Edelstein, H. Aktas, E. Turhan, D. M. Joel, C. Horev, and Y. Kapulnic. 2008. Physiological and biochemical changes at the rootstock-scion interface in graft combinations between Cucurbita rootstock and a melon scion. J. Hortic. Sci. Biotechnol. $83,777-783$.

Azizi, P., M. Y. Rafi, M. Maziah, S. N. A. Abdullah, M. M. Hanafi, M. A. Latif, A. A. Rashid, and M. Sahebi. 2015. Understanding the shoot apical meristem regulation: a study of the phytohormones, auxin and cytokinin, in rice. J. Mechanism of Develompent. 135. $1-15$.
BPS. 2011. Proyeksi Konsumsi Buah-Buahan Penduduk Indonesia. Badan Pusat Statistik. Jakarta.

Lestari, E.G. 2010. Peranan zat pengatur tumbuh dalam perbanyakan tanaman melalui kultur jaringan. J. AgroBiogen. 7 (1): 63-68.

Dengler, N.G. 2001. Regulation of vascular developmet. J. Plant Growth Regul. 20. 1-13.

Eleos. 2013. Pengaruh Konsentrasi Kinetin dan NAA Terhadap Induksi Tunas dan Akar pada Stek Batang Nenas. Artikel Ilmiah. Universitas Tanjungpura. Pontianak.

Hidayanto, M., S. Nurjannah, dan F. Yossita. 2003. Pengaruh panjang stek akar dan konsentrasi natrium nitrofenol terhadap pertumbuhan stek akar sukun (Artocarpus communis F.). J. Pengkajian dan Pengembangan Teknologi Pertanian. 2 (6): 154-160.

Hirose, N., K. I. Takei, T. Kuroha, T. K. Nobusada, H. Hayashi, and H. Sakakibara. 2008. Regulation of cytokinin biosynthesis, compartmentalization and translocation. J. Exp. Bot. 59. 75-83.

Kementan. 2015. Rencana Strategis Kementerian Pertanian 2015 - 2019. Kementerian Pertanian Republik Indonesia. Jakarta.

Kose, C. and M. Guleryuz. 2006. Effect of auxins and cytokinins on graft union of grapevine (Vitis vinivera) New Zealand. J. Crop Hortic. Sci. 34. 145-150.

Lakitan, B. 2001. Fisiologi Pertumbuhan dan Perkembangan Tanaman. PT Raja Grafindo Persada. Jakarta.

Ni'matur, R. 2014. Propagasi Akasia (Acacia mangium Willd) dengan Pemberian Kombinasi ZPT BAP (Benzyl Amino Purin) dan IBA (Indole Butyric Acid) secara In Vitro. Universitas Negeri Malang. Malang. (Skripsi).

Pakpahan, T. P., P. D. Bandem, dan Patriani. 2012. 
Pengaruh panjang entris terhadap keberhasilan sambung pucuk bibit jambu air. J. Sains Mahasiswa Pertanian. 1 (1): 19.

Qing, X., G. Shi-Rong, L. Lin, A. Ya-Hong, S. Sheng, and S. Jin. 2016. Proteomics analysis of compability and incompability in grafted cucumber seedling. J. Plant Physiology and Biochemistry. 105. 21-28.

Reinhardt, D., T. Mandel, and C. Kuhlemeier. 2000. Auxin regulates the initiation and radial position of plant lateral organs. Plant Cell 12. 507-518.

Salisbury, F. B. and C.W. Ross. 1995. Fisiologi Tumbuhan. Jilid I Terjemahan Diah R. Lukman dan Sumaryo. ITB. Bandung.

Setyaningrum, F. 2012. Pengaruh Konsentrasi BAP terhadap Pertumbuhan Awal Entres
Tiga Varietas Durian (Durio zibethinus Murr.) pada Perbanyakan Vegetatif Okulasi. Program Studi S1 Agroteknologi Universitas Sebelas Maret. Surakarta. (Skripsi Sarjana).

Sukarman, D., Rusmin dan Melati. 2002. Pengaruh asal sumber benih dan cara penyimpanan terhadap viabilitas benih jahe (Zingiber officinale L.). Prosiding Simposium IV Hasil Penelitian Tanaman Perkebunan. Bogor.

Widyastuti, N. dan D. Tjokrokusumo. 2007. Peranan beberapa zat pengatur tumbuh (ZPT) tanaman pada kultur In Vitro. J. Sains dan Teknologi Indonesia. 3 (5) 08.

Yuliyanto, A. G., E. Setiawan dan K. Badami. 2015. Efek Pemberian IBA terhadap Pertautan Sambung Samping Tanaman Srikaya. Agrovigor. 2 (8): 51-56. 